\title{
PLAUČIŲ VĖŽIO CHEMOTERAPIJOS PRINCIPAI
}

DR. MARIUS ŽEMAITIS

KMU PULMONOLOGIJOS IR IMUNOLOGIJOS KLINIKA

Reikšminiai žodžiai: plaučių vežys, chemoterapija.

Santrauka. Straipsnyje aptariami plaučių vèžio chemoterapijos principai.

Nustačius plaučių vėžio diagnozę ir ịvertinus navikinio proceso išplitimą bei ligonio būklę, nedelsiant turi būti pradètas plaučių vẻžio gydymas. Kokią plaučiuc vėžio gydymo taktiką taikyti, turi būti sprendžiama daugiadisciplinio aptarimo metu, o gydymas taikomas tose gydymo įstaigose, kuriose užtikrinamas reikiamas visų daugiadisciplinès komandos narių dalyvavimas, kompleksinis plaučių vẻžiu sergančių ligonių ištyrimas bei gydymas (chirurginis, spindulinis gydymas, chemoterapija).

Plaučių vẻžio gydymas priklauso nuo naviko histologijos (nesmulkiųjų ląstelių, smulkiųjų ląstelių plaučių vėžys), naviko išplitimo (TNM klasifikacija, stadija), ligonio funkcinès būklès, kvėpavimo sistemos funkcijos, gretutinių ligų, kūno masės sumažèjimo bei kitų prognozès veiksnių.

Chemoterapija yra smulkiųjų ląstelių plaučių vèžio gydymo pagrindas. Tuo tarpu gydant nesmulkiųjų ląstelių plaučių vẻžiu sergančius ligonius chemoterapija tradiciškai buvo skiriama esant metastazavusiam véžiui, vèliau pradèta derinti su spinduliniu ar chirurginiu gydymu lokaliai išplitusio véžio atveju ir tik keleri metai taikoma adjuvantiné chemoterapija, kuri skiriama ligoniams, sergantiems ankstyvu plaučių vèžiu po radikalios operacijos.

Chemoterapija platinos preparatu pagrindu pailgina geros funkcinès būklès pacientų, sergančių nesmulkiųjų ląstelių plaučių vẻžiu, gyvenimo trukmę, garantuoja simptomų kontrolę ir geresnę gyvenimo kokybę, palyginti su geriausia palaikomąja priežiūra.

\section{PROGNOZĖS VEIKSNIAI}

Priimant sprendimą dèl plaučių vèžio chemoterapijos, būtina įvertinti prognozès veiksnius. Vienais atvejais esant palankiai prognozei galima rekomenduoti agresyvesnę chemoterapiją numatant didesnę nepageidaujamų reiškinių tikimybę, kad būtų pailginta gyvenimo trukmè, kitais atvejais esant nepalankiai prognozei reikètų rinktis mažiau agresyvų gydymą, kad būtų pagerinta gyvenimo kokybė ir kontroliuojami simptomai.

Nesmulkiųjų ląstelių plaučių vèžio prognozès veiksniai:

- Ligoniams, kurių funkcinè būklè 0 ar 1 balas pagal ECOG, rekomenduojama chemoterapija.
- Nesmulkiųjų ląstelių plaučiuc vèžiu sergantiems ligoniams, kurių funkcinè būklè 2 balai pagal ECOG, rutinine chemoterapija nerekomenduojama, tikslinga spręsti individualiai. Jiems chemoterapija vienu trečios kartos antinavikiniu vaistu (monoterapija) rekomenduojama kaip pirmaeilis gydymas. Chemoterapija karboplatinos pagrindu ar redukuota cisplatinos doze rekomenduojama kaip gydymo alternatyva.

- Nesmulkiųjų ląstelių plaučiuc véžiu sergantiems ligoniams, kurių funkcinè būklè daugiau kaip 2 balai pagal ECOG, chemoterapija nerekomenduojama.

- Stadija. Mažesnè stadija lemia geresnę prognozę.

- Metastazių skaičius. Esant pavienei metastazei kai kuriais atvejais galima skirti agresyvesni gydymą.

- Kiti veiksniai (lytis, amžius, kūno masès netekimas, histologija) nèra pastovūs prognozès veiksniai. Chemoterapija vienu trečios kartos antinavikiniu vaistu (monoterapija) rekomenduojama kaip pirmaeilis gydymas vyresniems ligoniams. Chemoterapija platinos preparatuc pagrindu, galbūt redukuojant cisplatinos dozę, rekomenduojama kaip gydymo alternatyva geros funkcinès būklès vyresniems ligoniams, kurių organų funkcija pakankamai gera.

Smulkiųjų ląstelių plaučių vėžio prognozès veiksniai:

- Ligoniams, kurių funkcinė būklè 0 ar 1 balo pagal ECOG, rekomenduojama chemoterapija.

- Neišplitusiu smulkiųjų ląstelių plaučių vẻžiu sergantiems ligoniams, kurių blogą funkcinę būklę (3 ar 4 balai pagal ECOG) lemia plaučių véžys, rekomenduojama apsvarstyti chemoterapijos klausimą.

- Neišplitusiu smulkiųjų ląstelių plaučių vèžiu sergantiems ligoniams, kurių blogą funkcinę būklę (3 ar 4 balai pagal ECOG) lemia kitos būklès (ne plaučių véžys), chemoterapija nerekomenduojama.

- Esant išplitusiam smulkiųjų ląstelių plaučių véžiui ir blogai funkcinei būklei, chemoterapija nerekomenduojama.

\section{CHEMOTERAPIJOS SCHEMA}

\section{Nesmulkiųjų ląstelių plaučių vẻžys}

Pirmiausia rekomenduojama skirti chemoterapiją platinos preparatu pagrindu. Chemoterapija platinos pre- 
paratu (cisplatina ar karboplatina) ir vienu iš trečios kartos antinavikinių vaistų (gemcitabino, docetakselio, paklitakselio, vinorelbino) rekomenduojama kaip standartinis pirmos eilès nesmulkiųjų ląstelių plaučių vèžiu sergančių ligonių chemoterapinis gydymas, lemiantis ilgesnę gyvenimo trukmę, palyginti su chemoterapija platinos preparatu ir antros kartos antinavikiniu vaistu (pvz., etopozidu). Nè viena pirmos eilès chemoterapijos schema su platinos preparato ir trečios kartos antinavikiniu vaisto deriniu nėra pranašesnè už kitą. Chemoterapijos schemos, neturinčios platinos preparatų, galètú būti gydymo alternatyva, kai negalima skirti platinos preparatų. Nustačius nesmulkiųjų ląstelių plaučių vèžio progresavimą taikant pirmos eilès chemoterapiją ar po jos, rekomenduojama skirti antros eilès chemoterapiją docetakseliu, pemetreksedu ar erlotinibu. Trečios eilès chemoterapijai rekomenduojama skirti erlotinibą.

\section{Smulkiųjų ląstelių plaučių vėžys}

Neišplitusiam smulkiụjų ląstelių plaučių vẻžiui gydyti rekomenduojamas cisplatinos ir etopozido derinys yra veiksmingesnis už ciklofosfamido, doksorubicino ir vinkristino derinị. Cisplatiną pakeisti karboplatina galima tik tuo atveju, jei yra kontraindikacijų vartoti cisplatiną ar ji netoleruojama. Cisplatinos ir etopozido derini galima skirti kartu su spinduliniu gydymu. Esant išplitusiam smulkiųjų ląstelių plaučių vẻžiui rekomenduojama skirti cisplatiną ir etopozidą, bet kitų antinavikinių vaistuc veiksmingumas prilygsta cisplatinos ir etopozido deriniui. Esant smulkiųjų ląstelių plaučiuc vẻžio atkryčiui ar progresavimui, kai ligonio funkcinè būklė gera, tolesnè chemoterapija priklauso nuo atsako ì pirmos eilès chemoterapiją, ligonio funkcinès būklès bei laiko iki atkryčio ar progresavimo. Jei taikant pirmos eilès chemoterapiją atsako nebuvo, o atkrytis ar progresavimas nustatytas 2-3 ménesių laikotarpiu, smulkiưjų ląstelių plaučių vẻžys laikomas atspariu ir numatomo atsako ì gydymą dažnumas neviršija 10 proc. Jei laiko tarpas nuo chemoterapijos pabaigos iki atkryčio ar progresavimo viršija du (tris) mẻn., toks smulkiųjų ląstelių plaučių véžys laikomas jautriu, nes numatomas atsako dažnumas siekia iki 25 proc. Kai kurie tyrejjai nurodo, kad laiko riba, skirianti jautrų ir atsparų smulkiųjų ląstelių plaučių vėži, turètų būti 6 ménesiai. Jei laiko tarpas iki atkryčio ar progresavimo daugiau kaip 6 ménesiai, rekomenduojama kartoti pradinę chemoterapija, jei trumpesnis, rekomenduojama skirti iki tol netaikytą chemoterapijos schemą. Nustačius, kad topotekanas toks pat veiksmingas kaip ir CAV (ciklofosfamidas, doksorubicinas, vinkristinas) schema, jis buvo patvirtintas jautraus atsinaujinusio, progresuojančio smulkiųjų ląstelių plaučių vẻžio gydymo standartu. Nesant galimybių skirti topotekano, rekomenduojama CAV schema ar geriamasis etopozidas (pastarasis mažiau veiksmingas nei CAV derinys). Kaip gydyti atsparu (laiko tarpas trumpesnis kaip 2-3 mèn.) atsinaujinantị, progresuojantị smulkiųjų ląstelių plaučių vėži, nèra sutarta. Rekomenduojama CAV schema.

\section{CHEMOTERAPIJOS TRUKME்}

\section{Nesmulkiųjų ląstelių plaučių vẻžys}

Rekomenduojama skirti ne daugiau kaip 4-6 pirmos eilès chemoterapijos kursus. Rekomenduojami 2-4 neoadjuvantinès chemoterapijos kursai prieš chirurginị ar spindulini gydymą lokaliai išplitusio nesmulkiųjų ląstelių plaučių véžio atveju.

\section{Smulkiụjų ląstelių plaučių vėžys}

Esant neišplitusiam vėžiui prieš spindulini gydymą ar kartu su juo rekomenduojami 4 kursai, išplitusiam - 6 kursai.

Neretai antros ar trečios eilès antinavikiniais vaistais rekomenduojama gydyti, kol bus pasiektas maksimalus efektas, gydymas taps neveiksmingas arba kol atsiras netoleravimas dèl toksiškumo.

\section{ANTINAVIKINIŲ VAISTŲ SKAIČIUS, GYDYMO INTENSYVINIMAS}

\section{Nesmulkiųjų ląstelių plaučių vèžys}

Pirmos eilès chemoterapijai rekomenduojamas dviejų antinavikiniuc vaistų derinys. Gydant trimis antinavikiniais vaistais (išimtis bevacizumabo derinys su chemoterapija) gyvenimo trukmè akivaizdžiau nepailgèja, o nepageidaujamų reiškinių smarkiai padaugeja.

\section{Smulkiụjų ląsteliụ plaučiụ vèžys}

Šiuo metu chemoterapijos schemose nerekomenduojama didinti antinavikinių vaistų skaičiaus ir dozès ar keisti chemoterapijos schemas, nelemiančias kryžminio atsparumo, nes tai nepailgina gyvenimo trukmès, palyginti su standartiniu gydymu.

\section{Monoterapija}

Pirmos eilès chemoterapija trečios kartos antinavikiniais vaistais (monoterapija) pailgina nesmulkiụjų ląstelių plaučių vẻžiu sergančių ligonių gyvenimo trukmę ar pagerina gyvenimo kokybę, palyginti su geriausia palaikomąja priežiūra. Monoterapija rekomenduojama nesmulkiųjų ląstelių plaučių vèžiu sergantiems vyresniems ar blogesnès funkcinès būklès ( 2 balai pagal ECOG) ligoniams. Geriamasis etopozidas yra mažiau veiksmingas nei chemoterapija vaistų deriniais gydant smulkiųjų ląstelių plaučių věžiu sergančius ligonius.

\section{Gydymo veiksmingumo vertinimo metodika}

- Chemoterapijos veiksmingumas (radiologinis atsakas pagal RECIST kriterijus) vertinamas kas antrą chemoterapijos kursą, chemoterapijos toleravimas ir toksiškumas - nuolat.

- Jei yra atsakas ir chemoterapija toleruojama gerai, rekomenduojami 6 kursai.

- Jei liga stabili ar/ir chemoterapija toleruojama blogai dèl toksiškumo - 4 kursai.

- Jei liga progresuoja, keičiama i antros (ar trečios) eilès chemoterapiją arba chemoterapija nutraukia- 
ma ir skiriama geriausia palaikomoji priežiūra.

- Gydant lokaliai išplitusį nesmulkiųjų ląstelių plaučių věžĭ, prieš spindulinị arba operacinị gydymą skiriama:

- 2 chemoterapijos kursai - jei liga progresuoja ar chemoterapija blogai toleruojama dèl toksiškumo; - iki 4 chemoterapijos kursų - jei nustatomas atsakas ar liga stabili ir chemoterapija toleruojama gerai.

- Gydymo efektyvumo vertinimas:

- plaučiu naviko dinamikai įvertinti atliekama krūtinès ląstos rentgenograma, jei ji neinformatyvi krūtinès ląstos KT;

- metastazių dinamikai îvertinti tyrimo metodai parenkami pagal metastazių lokalizaciją.

- Baigus visą gydymo kursą atliekama kontrolinė krūtinès ląstos KT (jei buvo atlikta pradinė KT).

\section{CHEMOTERAPIJOS VIETA TAIKANT KOMBINUOTĄ PLAUČIŲ VËŽIO GYDYMA}

Plaučių vẻžiui gydyti taikomi keli būdai: chirurginis, spindulinis, chemoterapija, tačiau šiuolaikinis plaučių věžio gydymas dažniausiai grindžiamas gydymu derinant kelis būdus. Taigi labai svarbų vaidmenị atlieka daugiadisciplinis konkretaus ligos atvejo aptarimas.

\section{Adjuvantinẻ nesmulkiųjų ląstelių plaučių vẻžio che- moterapija}

Operacija yra ankstyvo nesmulkiųjų ląstelių plaučių vėžio gydymo standartas, tačiau tik nedidelè dalis ligonių operuojami, ir net prieš operaciją nustačius pirmos stadijos vẻži per penkerius metus miršta trečdalis. Pagrindiné tokio mirštamumo priežastis - plaučių vẻžio atkrytis su atokiosiomis metastazėmis. Taigi adjuvantinès chemoterapijos tikslas - sunaikinti mikrometastazes ir pagerinti ligos prognozę. Ilgą laiką adjuvantinè chemoterapija po radikalios operacijos nebuvo rekomenduojama, nes nebuvo nustatyta statistiškai reikšmingos įtakos ligonių gyvenimo trukmei. Situacija pasikeitè per paskutinius ketverius metus, kai klinikiniais atsitiktinių imčių tyrimais ir metaanalize írodyta, kad adjuvantine chemoterapija cisplatinos pagrindu statistiškai reikšmingai pailgina ligonių gyvenimo trukmę po radikalios ankstyvo nesmulkiųjų ląstelių plaučių véžio operacijos, palyginti vien tik su chirurginiu gydymu. Todèl adjuvantinè chemoterapija cisplatinos pagrindu rekomenduojama praejus 4-6 savaitėms po radikalios nesmulkiųjų ląstelių plaučių vėžio operacijos geros funkcinès būklès ( 0 ar 1 balai pagal ECOG) ligoniams, kurie visiškai atsitaise po operacijos ir neturi reikšmingų gretutinių ligų. Adjuvantinès chemoterapijos nauda įrodyta gydant II ir III stadijos radikaliai išoperuotą nesmulkiưjų ląstelių plaučių vèži. Po operacijos nustačius I stadiją, adjuvantinės chemoterapijos skirti nerekomenduojama, kitu atveju tolesnę gydymo taktiką reikètų aptarti daugiadisciplinès komandos pasitarime.

\section{Lokaliai išplitusio nesmulkiụjų ląsteliụ plaučiuc vèžio gydymas}

Lokaliai išplitusiam (III stadijos) nesmulkiųjų ląstelių plaučių vẻžiui pagal TNM klasifikaciją priskiriama nevienalytė grupė navikų - nuo rezektabilaus T3N1 iki nerezektabilaus T4N3 su piktybiniu pleuritu, kai taikoma tik chemoterapija. Todèl nèra vieno gydymo metodo šios grupès pacientams. Siekiant lokalios ir sisteminès kontrolès, pirmenybè teikiama daugiadisciplinei pagalbai ir kombinuotam gydymui. Labai svarbus vaidmuo tenka tiksliam navikinio proceso išplitimo, ypač tarpuplautyje, nustatymui (taip pat ir invaziniais tyrimo metodais) prieš planuojamą kombinuotą gydymą.

III B stadijos nesmulkiųjų ląstelių plaučių vẻžio gydymas didelių diskusijų nekelia, bet III A stadijos iki šiol tebèra diskusijų objektas. Geros funkcinès būklès (0 ar 1 balai pagal ECOG) III B stadijos (be piktybinio pleurito) ligoniams rekomenduojamas chemospindulinis gydymas. Chemospindulinis gydymas veiksmingesnis nei vien spindulinis gydymas. Sutampantis chemospindulinis gydymas veiksmingesnis, bet ir toksiškesnis nei nuoseklus chemospindulinis gydymas. Kai ligonio funkcinè būklè blogesnè (2 balai pagal ECOG), rekomenduojama apsiriboti tik spinduliniu gydymu.

III A1 ir III A2 pogrupio nesmulkiụjų ląstelių plaučių vėžio atveju priešoperacinio tyrimo metu išplitimas i tarpuplaučio limfmazgius nenustatomas, todèl tolesnè gydymo taktika priklauso nuo rezekcijos kraštų būklès. Jei N2 nustatyta operacijos metu ir rezekcijos kraštuose navikinès infiltracijos nerandama (R0), rekomenduojama pirmiau chemoterapija ir po to spindulinis gydymas arba chemospindulinis gydymas ir chemoterapija. Jei rezekcijos kraštuose nustatoma navikinė infiltracija (R1, R2), rekomenduojama pirmiau pooperacinis spindulinis gydymas ir po to chemoterapija arba chemospindulinis gydymas ir chemoterapija.

Dèl III A3 (potencialiai rezektabilaus) pogrupio nesmulkiųjų ląstelių plaučių vėžio gydymo nèra bendros nuomonès. Sudètines gydymas geriau nei vien tik chirurginis. Trečios fazès klinikinių atsitiktinių imčių tyrimų duomenys prieštaringi, todèl neoadjuvantinès chemoterapijos ir operacijos derinys vienų tyrejjų rekomenduojamas tik klinikiniuose tyrimuose, kitu - kaip gydymo standartas. Mes šiose rekomendacijose paliekame abi gydymo galimybes - pasirinkimą turètų lemti daugiadisciplinè komanda: neoadjuvantinè chemoterapija ir operacija arba chemospindulinis gydymas.

III A4 pogrupio ligoniai gydomi kaip ir III B stadijos nesmulkiųjų ląstelių plaučių vẻžiu sergantys ligoniai.

\section{Smulkiųjų ląstelių plaučių vẻžio kombinuotas gydymas}

Chemospindulinis gydymas sumažina lokalių atkryčių dažnumą ir pailgina neišplitusiu smulkiųjų ląstelių plaučių vẻžiu sergančių ligonių gyvenimo trukmę, 
palyginti vien su chemoterapija. Ankstyvas sutampantis chemospindulinis gydymas statistiškai reikšmingai pailgina neišplitusiu smulkiųjų ląstelių plaučių vẻžiu sergančių ligonių gyvenimo trukmę, palyginti su vèlyvu sutampančių ar nuosekliu chemospinduliniu gydymu, tačiau sutampantis chemospindulinis gydymas yra toksiškesnis. Taigi spindulini gydymą geros funkcinès būklès ligoniams rekomenduojama pradèti kartu su pirmu arba antru chemoterapijos kursu.

\section{PRINCIPLES OF LUNG CANCER CHEMOTHERAPY}

\section{MARIUS ŽEMAITIS \\ DEPARTMENT OF PULMONOLOGY AND IMMUNOLOGY KAUNAS UNIVERSITY OF MEDICINE}

Keywords: lung cancer, chemotherapy.

Summary. Literary data concerning principles of lung cancer chemotherapy have been presented.

\section{LITERATŪRA}

1. American College of the Chest Physicians (ACCP). Clinical practice guidlines for lung cancer prevention, diagnosis and treatment. Chest 2003; 123.

2. Antonelli G, Priolo D, Vitale F, Ferrau F. Locally advanced non-small cell lung cancer: different strategies for different diseases. Ann Oncol 2006 17: 24-27.

3. Arriagada R, Bergman B, Dunant A, et al. The International Adjuvant Lung Cancer Trial Collaborative Group: Cisplatin-based adjuvant chemotherapy in patients with completely resected non-small cell lung cancer. NEngl JMed 2004; 350 (4): 351-360.

4. Bria E, Ceribelli A, Trovo MG, et al. Non-small cell lung cancer: early stages. Ann Oncol 2006; 17: 17-21.

5. Chemotherapy in non-small cell lung cancer: Ametaanalysis using updated data on individual patients from 52 randomized trials. Non-Small Cell Lung Cancer Collaborative Group. Br Med J1995; 311: 899-909.

6. De Petris L, Crino L, Scagliotti GV, et al. Treatment of advanced non-small cell lung cancer. Ann Oncol 2006; 17: 36-41.

7. Douillard JY, Rosell R, De Lena M, et al. Adjuvant vinorelbine plus cisplatin versus observation in patients with completely resected stage IBIIIAnon-small cell lung cancer (Adjuvant Navelbine International Trialist Association [ANITA]): a randomised controlled trial. Lancet Oncol 2006; 7 (9): 719-727.

8. ESMOMinimum Clinical Recommendations for diagnosis, treatment and follow-up of non-small-cell lung cancer (NSCLC). Ann Oncol 2005; 16: i10-i12.

9. ESMOMinimum Clinical Recommendations for diagnosis, treatment and follow-up of small-cell lung cancer (SCLC). Ann Oncol 2005; 16: i7-i9.

10. Fischer JR, Ohnmacht U, Rieger N, Zemaitis M, Stoffregen C, Manegold $\mathrm{C}$, Lahm H. Prognostic significance of RASSF1 Apromoter methylation on survival of non-small cell lung cancer patients treated with gemcitabine. Lung Cancer 2007; 56 (1): 115-23.

11. Fossella F, Pereira JR, von Pawel J, et al. Randomized, multinational, phase Illstudy of docetaxel plus platinum combinations versus vinorelbine plus cisplatin for advanced non-small-cell lung cancer: the TAX 326 study group. J. Clin Oncol 2003; 21 (16): 3016-3024.

12. Furuse K, Fukuoka M, Kawahara M, et al. Phase Illstudy of concurent versus sequential thoracic radiotherapy in combination with mitomycin, vindesine, and cisplatin in unresectable stage Illnon-small-cell lung cancer. JClin Oncol 1999; 17: 2692-2699.

13. Gebbia V, Galetta D, De Marinis F. Non-small cell lung cancer patients with ECOGPS2: unsolved questions and lessons from clinical trias. Ann Oncol 2005; 16: 123-131.

14. Gridelli C, Aapro M, Ardizzoni A, et al. Treatment of advanced non-smallcell lung cancer in the eldery: results of an International Expert Panel. JClin Oncol 2005; 23: 3125-3137.

15. Hana N, Shepherd FA, Fossella FV, et al. Randomized phase IIItrial of pemetrexed versus docetaxel in patients with non-small-cell lung cancer previously treated with chemotherapy. JClin Oncol 2004; 22 (9):1589-1597.

16. Hotta K, Matsuo K, Kiura K, et al. Advances in our understanding of postoperative adjuvant chemotherapy in resectable non-small cell lung cancer. Curr Opin Oncol 2006; 18: 144-150

17. National Cancer Institute. Treatment statement for Health professionals Non-small cell lung cancer and small cell lung cancer. Pasiekta www. cancer.gov.

18. National Health and Medical Council. Clinical practice guidlines for the prevention, diagnosis and management of lung cancer. Sydney 2005. Pasiekta www.nhmrc.gov.au/publications

19. National Institute for Clinical Excellence. Lung cancer: the diagnosis and treatment of lung cancer. London 2005. Pasiekta www.nice.org.uk

20. NCCN(National Comprehensive Cancer Network) Clinical Practice Guidelines in Oncology - v.1.2007. Pasiekta www.ncen.org

21. Pass HI, Carbone DP, Minna JD, Johnson DH, Turrisi AT(ed.). Lung cancer: Principles and practice. 3rd edition. Lippincott Williams and Wilkins, Philadelphia, 2006.

22. Pfister DG, Johnson DH, Azzoli CG, et al. American Society of Clinical Oncology treatment of unresectable non-small-cell lung cancer guidlines: update 2003. JClin Oncol 2004; 22: 330-353.

23. Rosell R, Gomez-Codina J, Camps C, et al. Arandomized trial comparing preoperative chemotherapy plus surgery with surgery alone in patients with non-small-cell lung cancer. NEngl JMed 1994; 330 (3): 153-158.

24. Rosti G, Bevilacqua G, Bidol P, et al. Small cell lung cancer. Ann Oncol $2006 ; 17: 5-10$.

25. Sandler A, Gray R, Perry MC, et al. Paclitaxel-carboplatin alone or with bevacizumab for non-small-cell lung cancer. NEngl JMed 2006; 355: 2542-2550.

26. Schiller JH, Harrington D, Belani CP, et al. Eastern Cooperative Oncology Group. Comparison of four chemotherapy regimen for advanced nonsmall-cell lung cancer. NEngl JMed 2002; 346 (2): 319-323.

27. Scottish Intercollegiate Guidlines Network (SIGN). Management of patients with lung cancer. Anational clinical guidline. Edinburgh 2005. Pasiekta www.sign.ac.uk

28. Shepherd FA, Fdancey J, Ramlau R, et al. Prospective randomized trial of docetaxel versus best supportive care in patients with advanced nonsmall-cell lung cancer previously treated with platinum-based chemotherapy. JClin Oncol 2000; 18 (10): 2095-2103.

29. Shepherd FA, Rodrigues Pereira J, Ciuleanu T, et al. Erlotinib in previously treated non-small-cell lung cancer. NEngl JMed 2005; 353 (2): 123-132.

30. Spira A, Ettinger DS. Multidisciplinary management of lung cancer. NEngl JMed 2004; 350: 379-392.

31. Spiro SG(ed.). Lung cancer. Eur Respir Mon 2001, p.329.

32. Trodella L, D'Angelillo RM, Granone P. Multimodality treatment in locally advanced non-small cell lung cancer. Ann Oncol 2006; 17: 32-33.

33. 42nd annual meeting of American Society of Clinical Oncology. 2006 Educational book. Alexandria, VA, 2006. 